\title{
Perspectives of Entrepreneurial Orientation with the Quality of Life
}

\author{
*Salima Hafeez ${ }^{1}$, Asif Mehmood Rana ${ }^{1}$, Rashid Mehmood Chaudhry ${ }^{1}$, Muhammad Aslam Khan², H.Mushtaq \\ Ahmad $^{1}$, Kashif Ur Rehman ${ }^{1}$ \\ 1'Iqra University, Islamabad, Pakistan \\ 2Preston University, Islamabad, Pakistan \\ *salimahafeez@yahoo.com
}

\begin{abstract}
The characteristics of entrepreneurial orientation is played important role in business. How do an entrepreneurial firms and individuals have taken the advantage in industry? This study explores the dynamic capabilities of the organization according to international performance. Our findings indicates the positive impact on dynamic capabilities of the business with perfectly use of this research framework. The main aspect of this paper is to analyse the impact of entrepreneurial orientation with the quality of life. Distinctive features of entrepreneurs and their contribution to the economy can make it possible for third world countries to grow their economies faster and provide financial means to enhance social, health, and environmental well-being (basic dimensions of quality of life), along with products and services that the poor need in these countries. Entrepreneurial orientation combined with organization learning and Quality of life (QOL) are enhanced the dynamic capability of the organization. Present conceptual research will provide the source of competitive advantage and mainstream line for further development of the business.We suggest that existing literature reconfiguring the different approaches for the entrepreneurial to capture the opportunities in world business. First, quality of life cannot possibly improve in inactive or weakening economic conditions; second, economic development in the third world countries cannot advance in a balanced and desirable manner without a major domestic entrepreneurship movement (Samli 2004, 2008a).
\end{abstract}

Keywords: Entrepreneurial orientation, organizational learning, quality of life, dynamic capabilities

\section{Introduction}

Entrepreneur play a vital role in the development process and build the strong economy, creates employment opportunities boost business practices, provide reasonable infrastructure, and promote new strategies for innovation and change. The entrepreneur brings the innovation, take the risk and always adopt the proactive approach to achieve the desire goal (Slevin \& Covin, 1989). In the society especially in the third world countries, there is need to enhance the process of entrepreneurial orientation. The policy makers give the importance of risk and time factors whether it is short term risk or in a long term risk. Lack of entrepreneur skills shows that we are reluctant to adopt the change and still living in an old conservative style (Yu, 2010). Whereas all entrepreneurs should be aware with the substance of risk that brings the positive change and innovation .Most of the time when we think about the risk then fear of loss comes in our mind how we can tackle and cope this sort of fear. We must need to adopt the rational approach towards risk taking decision.

To evaluate the development of entrepreneurship orientation, several measures can be used like Innovativeness, Risk-Taking, with the pro-activeness; these factors will bring the positive impact on the entrepreneur capabilities. How can an individual polish his skills and enhance his capabilities through entrepreneurship orientation? There are barriers that influence learning transfer process, these comes on individual level, group level, organization level and societal level (Schilling and Kluge 2008; Sun and Scott, 2005). An entrepreneur must have the capability to learn teamwork with the continuous improvement, by the sharing of ideas and knowledge and reframe the things where change is required; by doing this we can enhance the learning process in the organization (Huber, 1991). This study emphasis about those people who are being ignored in the society, how the entrepreneur can give them space for survival by creating various sort of opportunities. Entrepreneur has the strength to contribute in the economy and develop the entrepreneurship culture means provide facilities social, health, economical and environmental well-being in the form of goods and services and maintain the quality of life (Coskun and Samli, 2008). 
The concept of quality of life can be easy to understand with the Maslow's hierarchy of need that is placed in five category, according to him if persons first and $2^{\text {nd }}$ need fulfil then he think about the quality of life "which can be defined as that satisfaction we get from doing what we want to do instead of what we do it for and a sense of progress towards becoming more competent to meet our needs over time" (Lewis, 2000). When lower level of need met the upper level of need become more important, in the developing countries mostly people struggle in their life to the fulfilment of first two needs. In an enterprises point of view people should not treat like a machine, they have a purpose; they expect to achieve these purposes met in the conduct of their life (Lewis, 2000). Employees should be managed like a partner, the people management is the marketing job, in marketing one does not start with the question: what do we want? We should begin with the question: what does the other party want? In fact, the highest organization goal can be achieve when employees are enabled to meet their individual needs in performing to meet the organization needs or it is not a need, it can be an expectation. The quality of life needs continuous improvement. The question is that how can an entrepreneur improve the quality of life for its employees?

\section{Literature Review}

Today economic activities are spread beyond the border of the countries and new opportunity shown for the entrepreneurs to gain valuable profit through competitive advantage, it creates the competition environment for the entrepreneurs (D'Aveni, 1994). Modern way of production and unlimited trade boundaries lead the contest, it is too much difficult for the investor to survive due to world trade concept to reduce the tariffs and duties among the nations and regional trade agreement, proactive approach required to maintain the proper competition and reduce the risk of competitors attack, has taken suitable course of action and build new techniques to take the edge from other (Harvey, Griffith, 2001). New concepts have introduced for energetic capabilities of business, a strong foundation of a firm depend on economic resources of the firms, on base of resources firm behave better way and develop the creativity to lay down competitors and invest on research and development to make the competitive advantage against its competitor and run according to market demand, market trend and market innovation. Various studies have developed the relationship and defined the procedure ,how dynamic impact of innovation factor on capabilities of the business to make the unique mechanism for operations ( Ambrosini and Bowman,2009; Iansiti and clark,1994; Zott,2003; Zollo and Winter,2002;Zahra and George,2002;Lawson and Samson,2001;Collis,1994;Griffith and Harvey,2001).

\section{Hypothesis 1: Entrepreneurship orientation has significant impact on the Dynamic Capabilities.}

Focus of study is explained the factors who effect the environment of the organization and ability of entrepreneurs (Teece, 2007). Entrepreneurs have reduced the risk factor due to vibrant skills, abilities and creativity, build up the modern way of techniques in business (Samson and Lawson, 2001). Entrepreneurship provides ground of information with in business and with the business, energizes the system to move forward and increase the area of operations (Tsoukas and Mylonopoulos, 2004; Zahra, 1999). Dynamic capabilities and proper used of economic resources provide the opportunities to entrepreneurs for attain the business targets easily (Jiang, 2010; Yu, 2010; Hao, 2010). How to polish the organizational skill, make procedures strong, and enhance vibrant capabilities, managerial wisdom and practice through facts (Vera and Cepeda, 2007). Under deliberate arrange of a business entrepreneurs gain lot of information about organization, these information are mostly productive for output and build the network between the stakeholders ,provide base for culture to sharing the personal knowledge to each other, basically existing knowledge area of the firm promote(Mylonopoulos,Tsoukas,2004). When sound interaction developed between entrepreneurship and understanding margin also increase due to experience vice, information sharing and entrepreneurial orientation (Jantunen et al, .2005). Creativity comes with the failure of risk (Harvard Business review, 2011).

The practical results shown those entrepreneurial orientations have positive integration with dynamic capabilities and enhance the operation quality .Consequently, organizational learning, build the positive image of entrepreneur reflects an affective image on dynamic capabilities in different areas (Hao, 2010; Jantunen, 2005). Organization has taken strategic action to find out a new market and develop the new business with highly effective course of actions, Entrepreneurial approach to decision making directed a strategic path for multinational perspective of management (Slevin and Covin, 1989). So, entrepreneurial orientation present business environment and shown the strategic model for examine the impression 
within the organization and with the organization (Dess and Lumpkin, 1996, 2001). Organization creativity develops through existing resources of the organization with linked of organizational learning.

\section{Hypothesis 2: Organizational learning has significant impact on Dynamic Capabilities.}

Other side, business community initiates the new techniques and enhance the technology to provide the competitiveness base for new set up, increase the area of capabilities, improvement in operations and process (Zahra et al., 1999). Commercial Entrepreneurship developed new business model with unique business values, innovation and share the operations with other entrepreneurs on the origin of running organizations resources to spark the capabilities (Dess et al., 2003). In present study, innovativeness, risk taking and creativeness have linked to define the scale of entrepreneurial orientation (Wiklund and Shpepherd, 2005; Covin, Green and Slevin, 2006; Naman and Slevin, 1993; Zahra and Covin, 1995). Participant of the managerial positions clarified organizational culture as proceed to reduce the risk factors whose create the hurdle during the operations and rotate the design to overcome the member's friction regarding to cooperation and interaction to perform the activities in right direction (Schon and Argyris, 1978). Organizational wisdom stimulate the course of actions to create and introduced interlink the abilities of members and rich the information based knowledge to increase the boundaries of activities for organization output (Lyles and Fiol, 1985). Regarding to knowledge perspective organizational knowledge categories in different areas, first how get the knowledge, where maximize function and translate the information in easy mode of communication, properly pervasive in the members mind (Huber, 1991).

Evaluated with the insistent prospector strategy and unreceptive defender strategy, the analyzer strategy, which emphasizes both refining current routines for a secured return and generating incremental innovations for future market needs, has generated superior financial rewards (Luo \& Park, 2001). The irregularity of the environment prevents entrepreneurial firms from proceeding proactively and aggressively, and their motivation and willingness to grow and expand are constrained (Lau \& Busenitz, 2001). Consequently, informatics environment and data have useful due to highly capable knowledge and learning process nothing without that, as well as on four steps of Knowledge invention, refinement, endorsement and dispersion (Bontis, 1998). Different stages of learning developed more interested way of learning and provide bridge to entrepreneurs to achieve the business target with interface the activities for learning according to the nature of the organization and adopt a strategic approach with all steps of learning (Crossan et al., 1999).

Mostly Scholar examined that dynamic capabilities understand in various perspective, no firm kept the edge without unique competency to the other one, these abilities build the relationship of enterprises and connected the sound entrepreneurial network among the members, on the presence of this type of internal innovation and rearrange the all system who intend to reduce the speed of organization according to international pace (Harvey and Griffith, 2001; Teece et al., 1997). How does unique strengths play a progressive role in organizational up stream, conversion and downstream activities, in connection with these activities output of the organization based on dynamic strategies and continuous improvement of technology ,new fruition in business process and improve present working environment (Zahra et al.,2006;Winter,2003;Helfat and Peteraf,2003;Collis,1994;Iansiti and Clark,1994;Eisenhardt and Mrtin,2000;Lawson \& Samson,2001;Zahra and George,2002;Zello and Winter,2002). Focus of these Scholars colours the features and modern interpretation of dynamic strategy and do away with the synonymic replication in explanation of dynamic strategies.

\section{Hypothesis 3: Quality of life has the significant impact on the Dynamic Capabilities.}

Dynamic strategies are diversified in nature according to above discussion. There are areas of dynamic strategies where these are behave in ecology sensing ,secondly modify an revitalization and working as scientifically in elastic .Dynamic strategies have proceeded in a organization such as twistable according to the requirement of the situation (Li,2006; Lawson and Samson, 2001; Prahalad, Hamel 1994; Collis,1994;Clark,1994;Chandler,1962;Nelson \& Winter,1982). Correspondingly, these strategies give an idea about the creativity, elasticity and make over the industries capabilities, build the organizational culture according to reaction of the environment prevail in the competitive business world. 


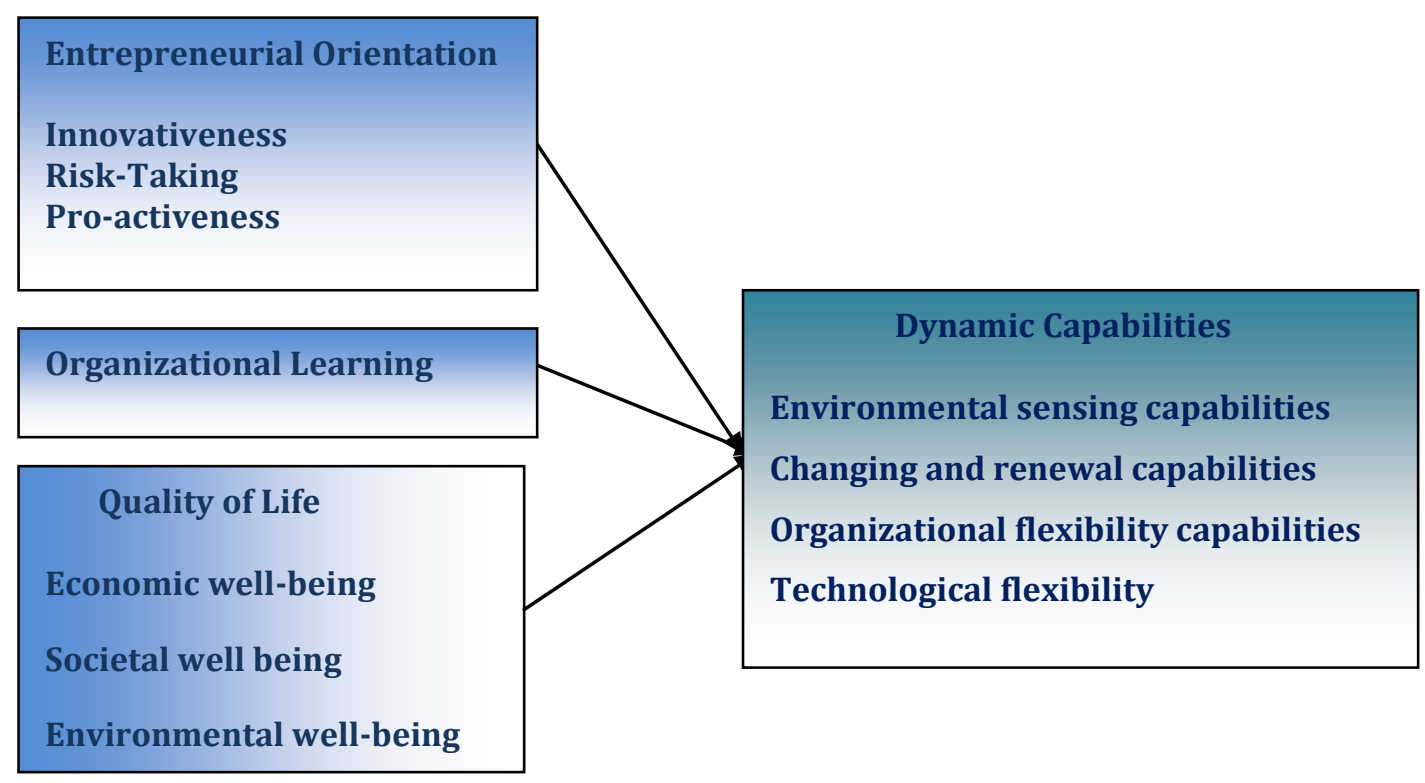

Discussion: Mostly studied define the role of entrepreneurs awareness regarding to their business and same level of mechanism to ward economic growth and business profitability are present the signs of quality of life, especially in developing and integrate with third world countries such as, Pakistan. Economic activities and economic development is primary factor to increase the quality of life of individual, these are poor population of third world countries, particularly in Pakistan where poverty is increase in high rate. As par previous discussion quality of life is not consider on level of necessity for a measurement of entrepreneur's quality of life. Individual income of a persons have effective role to meet the basic needs but a satisfaction level is not meet and turn into enhance the quality of life systematically. Satisfaction with respect to necessary needs is essential but sometime this satisfaction level not to be ample to elevate the quality of life.

Effective businesses planning of an entrepreneur reduce the poverty of individual as a long way to provide the opportunities to the peoples fulfill the basic needs toward satisfactory level. It is plan to establish innovative and proactive approach for availability of these products and services that are designed according to customers demand and confirm the availability of these products and services for the society. This research finds out the five parts where economic benefits not to be play effective role to increase the quality of life. Very first part is not extravagant to reduce the economic gains. More ever the autocratic approach is opposed the tax on economic gain. Population factor is also homicide economic development of the country, in other hand new opportunity emerges to build the Entrepreneurship economic development and quality of life. As with other recent studies, we found extra support for Lumpkin and Dess's (1996) argument that entrepreneurial orientation may have more of a moderating effect in forecasting firm performance. The excess of the entrepreneurial orientation could encourage the firm to seek international opportunities (McDougall et al., 1994).

Entrepreneurs have natural skills, abilities and characteristics to find the business opportunities. Entrepreneur is good predictor of risk, well informed with related industry and management ability to cope the business activities and take the competitive advantage from their rivalries. According to the current situation manager, adopt the local culture approach to take the result oriented decision-making process to achieve business objective. In the same way, collections of data and preserving information may and may not meet the entrepreneur purpose regarding the decision-making. In cultural perspective personal achievement and motivation, mark is not it all. There has to be a certain level of ambition to be an entrepreneur and to succeed. Entrepreneurs are risk takers and risk managers. Once again, the risk taking and risk managing capabilities differ in different cultural settings. These capabilities are closely related to how the risk is perceived in that culture. 
Finally, not all people have the same equal ability to make critical decisions to manage. Thus, managerial skills that are needed for entrepreneurs vary significantly (Baker et al. 2005). Entrepreneurship is new and it is about frequent innovation and creativity. It is the future of business schools and it should begin to move into a leadership role. Today, the words used to describe the innovation regime of the 21st century are: dream, create, explore, invent, pioneer, and imagine! Entrepreneurship educators must have the same innovative drive that is expected from entrepreneurship students. Four processes are central to the description of how organizations develop toward internal fit and their transitions between such configurations of tightly reinforcing elements are as follows: thickening (reinforcement of an existing core element by new elaborating elements), patching (creation of a new core element and its reinforcement by new elaborating elements), coasting (no further elaboration of a new core element in a given period), and trimming (deletion of core element and its elaborating elements).

When entrepreneurial opportunities are matched by skills of the enterprising individuals in that culture, the result is faster than usual economic growth. This may be particularly true for the poor. While global giants ignore the poor markets of the world and domestic large firms emphasize sizable and profitable domestic markets, entrepreneurs fill a large void by serving the poor. Thus, entrepreneurs play an important role in economic growth. They provide jobs and help sustain a certain standard of living among the poor leading to improvement in quality of life among the poor. Currently the institutional environment of China for entrepreneurial business is dynamic yet volatile, and to some extent, still subject to governmental and nonmarket decisions and activities. In order to deal with such a situation, SMEs have to spend already limited resources on non-market activities such as gift-giving, banquets, and donations, which are essential to establish personal networks (i.e.,guanxi) and to provide a buffer for their weak legitimacy in the market (Ahlstrom \& Bruton, 2002). The unpredictability of the environment prevents entrepreneurial firms from proceeding proactively and aggressively, and their motivation and willingness to grow and expand are constrained (Lau \& Busenitz, 2001). Modern organizations need to operate as entrepreneurial businesses that are stable across situation and time.

\section{Conclusion and Future Research}

This research article bringing the motive about the entrepreneur quality of life about the poor countries of the world. The rich people are getting richer and the poor much poorer. To identify this problem, we have proposed the concept about the quality of life. This is designed to benefit poor countries and especially the poor segments in third-world countries. How we can achieve the motive of Quality of life? By providing the necessities of life in the economy that environment would also fulfilling the basic needs of the society as well as enhance quality of life. How is it possible? If all the resources would be properly utilized in the economy than majority of people can reach the satisfaction level. This is seems unrealistic approach but it is necessary for improving the quality of life there is need to create awareness to the investors.

This study examines the relationship between the Quality of Life (QOL) and entrepreneur orientation. The main purpose of the study is how to enhance the quality of life by polishing the capabilities. Entrepreneurial orientation has the three dimension risk-taking, innovativeness and pro-activeness are correlated to each other but also a relatively independent in nature (Lumpkin and Dess,1996).We can say if any two variable are powerful than organization is entrepreneurial oriented. Quality of life can be promoted by adopting the dynamic capabilities. The entrepreneur is the person who can improve the quality of life of the individuals and society. Because of the extensive interview, concludes that qualities of life consist of economic well being and social and environmental well-being that increases the dynamic capabilities of the individuals.

\section{References}

Ahlstrom, D. \& Bruton, G. D. (2002). An institutional perspective on the role of culture in shaping strategic actions by technology-focused entrepreneurial firms in China. Entrepreneurship Theory \& Practice, 26(4), 53-69.

Ambrosini, V. \& Bowman, C. (2009). What are dynamic capabilities and are they a useful construct in strategic management? International Journal of Management Reviews, 11(1), 29-49. 
Argyris, C. \& Schön, D. A. (1978). Organizational Learning: A Theory of Action Perspective. Reading, MA: Addison-Wesley.

Baker, T., Gedajilovic, E. \& Lubatkin, M. (2005). A framework of comparing entrepreneurship processes across nations. Journal of International Business Studies, 36(5), 492-506.

Bontis, N. (1998). Intellectual capital: An exploratory study that develops measures and models. Management Decision, 36(2), 63-76

Cepeda, G. \& Vera, D. (2007). Dynamic capabilities and operational capabilities: A knowledge management perspective. Journal of Business Research, 60(3), 426-437.

Chandler, A. D. (1962). Strategy and Structure: Chapters in the History of the American Industrial Enterprise. Cambridge, MA: MIT Press

Coskun, P \& Samli, A. C. (2008). Entrepreneurship Economic Development and Quality of Life in ThirdWorld Countries. Applied Research Quality Life, 3, 203-213.

Collis, D. J. (1994). Research note: How valuable are organizational competence. Strategic Management Journal, 15, 143-152.

Covin, J. G. \& Slevin, D. P. (1989). Strategic management of small firms in hostile and benign environments. Strategic Management Journal, 10(1), 75-87.

Covin, J. G., Green, K. M. \& Slevin, D. P. (2006). Strategic process effects on the entrepreneurial orientation sales growth rate relationship. Entrepreneurship Theory and Practice, 30, 57-81.

Crossan, M., Lane, H. W. \& White, R. E. (1999). An organizational learning framework: From intuition to institution. Academy of Management Review, 24(3), 522-538.

D'Aveni, R. A. (1994). Hyper-competition: Managing the Dynamics of Strategic Manoeuvring. New York: The Free Press

Dess, G. G. (2001). Linking two dimensions of entrepreneurial orientation to firm performance: The moderating role of environment and industry life cycle. Journal of Business Venturing, 16(5), 429451.

Dess, G. G., Ireland, R. D., Zahra, S. A., Floyd, S. W., Janney, J. J. \& Lane, P. J. (2003). Emerging issues in corporate entrepreneurship. Journal of Management, 29(3), 351-378.

Eisenhardt, K. M. \& Martin, M. (2000). Dynamic capabilities: What are they? Strategic Management Journal, 21(10), 1105-1121.

Fiol, C. M. \& Lyles, M. (1985). Organizational learning. Academy of Management Review, 10, 803-813.

Griffith, D. A. \& Harvey, M. G. (2001). A resource perspective of global dynamic capabilities. Journal of International Business Studies, 32(3), 597-606.

Hamel, G. \& Prahalad, C. K. (1994). Competing for the Future. Boston, MA: Harvard Business School Press.

Hao, J. (2010). School of Business, Fudan University, Shanghai 200433, China.

Helfat, C. E. \& Peteraf, M. A. (2003). The dynamic resource-based view: Capability lifecycles. Strategic Management Journal, 24(10), 997-1010.

Huber, G. P. (1991). Organizational learning: The contributing processes and the literatures. Organization Science, 2(1), 88-115.

Iansiti, M. \& Clark, K. B. (1994). Integration and dynamic capability: Evidence from product development in automobiles and mainframe computers. Industrial and Corporate Change, 3(3), 557-605.

Jantunen, A., Puumalainen, K., Saarenketo, S. \& KylÃheiko, K. (2005). Entrepreneurial orientation, dynamic capabilities and international performance. Journal of International Entrepreneurship, 3, 223-243.

Jiang, W. (2010). School of Business, Zhejiang University, Hangzhou 310058, China.

Lawson, B. \& Samson, D. (2001). Developing innovation capability in organizations: A dynamic capabilities approach. International Journal of Innovation Management, 5(3), 377-400.

Lau, C. M. \& Busenitz, L. W. (2001). Growth intentions of entrepreneurs in a transitional economy: The People's Republic of China. Entrepreneurship Theory \& Practice, 26(1), 5-20.

Lewis, L. (2000). Working Together: 12 principles for Achieving Excellence in Managing Projects, Teams, and organization, Publisher-McGraw Hill, Chicago, London, New Delhi, and Toronto, 34-37.

Li, X. (2006). Dynamic Capabilities Theory: Identification, Construction and Formation Mechanism, 52-67.

Lumpkin, G. T. \& Dess, G. G. (1996). Clarifying the entrepreneurial orientation construct and linking it to performance. Academy of Management Review, 21(1), 135-172.

Luo, Y. \& Park, S. H. (2001). Strategic alignment and performance of market-seeking MUCs in China. Strategic Management Journal, 22, 141-155.

McDougall, P. P., Shane, S. \& Oviatt, B. M. (1994). Explaining the Formation of International New Ventures: The Limits of Theories from International Business Research. Journal of Business Venturing, 9, 469-487. 
Naman, J. L. \& Slevin, D. P. (1993). Entrepreneurship and the concept of fit: A model and empirical tests. Strategic Management Journal, 14, 137-153.

Nelson, R. R. \& Winter, S. G. (1982). An Evolutionary Theory of Economic Change. Cambridge, Mass: Belknap Press of Harvard University Press.

Samli, A. C. (2004). Entering and succeeding in emerging countries. Masons, Ohio: ThomsonSouthwestern.

Samli, A. C. (2008a). Globalization from the bottom-up. New York: Springer.

Schilling, J. \& Kluge, A. (2008). Barriers to organizational learning: an integration of theory and research. International Journal of Management Reviews, 10(2).

Sun, P. Y. T. \& Scott, J. L. (2005). Sustaining second order change initiation: structured complexity and interface management. Journal of Management Development, 24, 879-895.

Teece, D. J. (2007). Explicating dynamic capabilities: The nature and microfoundations of (sustainable) enterprise performance. Strategic Management Journal, 28(4), 1319-1350.

Teece, D. J., Piano, G. \& Shuen, A. (1997). Dynamic capabilities and strategic management. Strategic Management Journal, 18(7), 509-533.

Tsoukas, H. \& Mylonopoulos, N. (2004). Organizations as Knowledge Systems: Knowledge, Learning and Dynamic Capabilities. New York: Palgrave Macmillan.

Wiklund, J. \& Shepherd, D. (2005). Entrepreneurial orientation and small business performance: A configurational approach. Journal of Business Venturing, 20, 71-91.

Winter, S. G. (2003). Understanding dynamic capabilities. Strategic Management Journal, 24(10), 991995.

Yu, C. (2010). School of Business, Fudan University, Shanghai 200433, China.

Zahra, S. A. \& Covin, J. G. (1995). Contextual influences on the corporate entrepreneurship-performance relationship: A longitudinal analysis. Journal of Business Venturing, 10(1), 43-58.

Zahra, S. A. \& George, G. (2002). The net-enabled business innovation cycle and the evolution of dynamic capabilities. Information Systems Research, 13(2), 147-151.

Zahra, S. A., Nielsen, A. P. \& Bogner, W. (1999). Corporate entrepreneurship, knowledge, and competence development. Entrepreneurship: Theory and Practice, 23(3), 169-190.

Zahra, S. A., Sapienza, H. J. \& Davidsson, P. (2006). Entrepreneurship and dynamic capabilities: A review, model and research agenda. Journal of Management Studies, 43(4), 917-955.

Zott, C. (2003). Dynamic capabilities and the emergence of intra-industry differential firm performance: Insights from a simulation study. Strategic Management Journal, 24(2), 97-112.

Zollo, M. \& Winter, S. G. (1999). From organizational routines to dynamic capabilities. Working Paper of the Reginald H. Jones Center, the Wharton School University of Pennsylvania.

Zollo, M. \& Winter, S. G. (2002). Deliberate learning and the evolution of dynamic capabilities. Organization Science, 13(3), 339-351. 